\title{
PENANAMAN ETIKA KOMUNIKASI BISRI MUSTOFA DALAM PROSES PEMBELAJARAN DI MA NURUL ISLAM BOYOLALI
}

\author{
Wahid Tuftazani Rizqi \\ Universitas Islam Negeri Sunan Kalijaga, Yogyakarta, Indonesia \\ wahidtuftazani95@gmail.com
}

\begin{abstract}
This study aims to explore Bisri Mustofa's conception of the ethics of community communication and its application in MA Nurul Islam Boyolali. This research is a qualitative field research with a case study approach. The paradigm used is constructivism-interpretive paradigm. The data analysis technique goes through three stages, namely data reduction, data presentation, and drawing conclusions. The concept used in this research is the learning concept of Bisri Mustofa. The results conclude that: Bisri Mustofa's conception in education is to pay special attention to how to convey information to others in good language, and the absence of one's feelings in communicating. This conception can be instilled in the community through education by paying attention to learning, learning methods, and evaluating learning objectives. In its application, Madrasah Aliyah Nurul Islam Boyolali seeks to apply this conception by paying attention to the learning implementation plan and also the learning process.
\end{abstract}

Keywords: Communication Ethics, Ethical Education, Learning Process, Bisri Mustofa

\begin{abstract}
Abstrak
Penelitian ini bertujuan untuk menggali konsepsi Bisri Mustofa dengan etika komunikasi didalam masyarakat dan Penerapannya di MA Nurul Islam Boyolali. Penelitian ini merupakan penelitian lapangan yang bersifat kualitatif dengan pendekatan studi kasus. Paradigma yang digunakan adalah paradigma konstruktivisminterpretatif. Teknik analisis datanya melalui tiga tahapan, yakni reduksi data, penyajian data, dan penarikan kesimpulan. Konsep yang digunakan dalam penelitian ini adalah konsep pembelajaran Bisri Mustofa, Hasil penelitian menyimpulkan bahwa: Konsepsi Bisri Mustofa dalam pendidikan etika ialah memberikan perhatian khusus pada bagaimana menyampaikan informasi kepada orang lain dengan bahasa yang baik, bahasa yang halus, dan tidak menyakiti perasaan seseorang dalam berkomunikasi. Konsepsi ini dapat ditanamkan pada masyarakat melalui jalan pendidikan dengan memperhatikan pada tujuan pembelajaran, metode pembelajaran, dan evaluasi pembelajaran. Dalam penerapannya, Madrasah Aliyah Nurul Islam Boyolali mengupayakan penerapan konsepsi tersebut dengan memperhatikan rencana pelaksanaan pembelajaran dan juga proses pembelajarannya.
\end{abstract}

Kata Kunci: Etika Komunikasi, Pendidikan Etika, Proses Pembelajaran, Bisri Mustofa

\section{PENDAHULUAN}

Undang-Undang Dasar 1945 pasal 31

ayat 3 menyatakan bahwa pemerintah mengusahakan dan menyelenggarakan satu sistem pendidikan nasional, yang meningkatkan keimanan dan ketakwaan serta ahlak mulia dalam rangka mencerdaskan kehidupan bangsa (UUD 1945). Kemudian, pendidikan diartikan sebagai suatu usaha sadar dan terencana guna mewujudkan suasana belajar dan proses pembelajaran peserta didik secara aktif untuk mengembangkan potensi dirinya agar memiliki kekuatan spiritual keagamaan, kepribadian, akhlak mulia, serta keterampilan yang diperlukan dirinya, masyarakat, bangsa dan negara (UU Sisdiknas, 2003). Dengan dasar ini, negara memiliki kewajiban menyelenggarakan pendidikan untuk membentuk manusia yang memiliki kepribadian baik, kecerdasan yang maju, serta memiliki kekuatan spiritual yang bisa menjadikan seseorang berakhlak mulia.

Undang-Undang RI No 12 Tahun 2012 tentang Pendidikan Tinggi, didalam Pasal 5 
disebutkan bahwa pendidikan tinggi diantaranya bertujuan untuk mengembangkan potensi Mahasiswa menjadi manusia yang beriman dan bertakwa kepada Tuhan Yang Maha Esa dan berakhlak mulia (UU RI, 2012). Berdasarkan keterangan diatas, sangat jelas mengenai tujuan pendidikan di Indonesia, yakni untuk membentuk bangsa Indonesia agar memiliki watak yang bermartabat, menjadi manusia yang memiliki iman dan takwa kepada Allah swt, dan juga memiliki akhlak yang mulia dalam kehidupan berbangsa dan bernegara. Dengan tujuan pendidikan yang demikian, seharusnya lembaga pendidikan baik dari tingkat dasar, menengah, maupun pendidikan tinggi melahirkan manusia yang beriman, bertakwa, dan memiliki akhlak serta etika yang baik dalam berinteraksi dan berkomunikasi dengan masyarakat.

Namun dalam kenyataannya, masih banyak ditemukan persoalan mengenai buruknya etika dalam berkomunikasi di masyarakat. Salah satunya dalam laman Detik.com disebutkan, tingkat kesopanan warganet atau netizen Indonesia menempati urutan terbawah se-Asia Tenggara (Dewi, 2021). Ini artinya masyarakat Indonesia dalam berkomunikasi didunia digital memiliki tingkat kesopanan paling buruk. Hal ini ditambah dengan kemudahan akses bagi siapapun untuk dapat mengekspresikan dirinya di media sosial, sehingga komunikasi antar individu tidak lagi secara langsung namun lebih banyak melalui media virtual (Nurrachmi \& Puspita, 2018).

Problem ini juga menjadi perhatian dari Kemendikbud berkaitan dengan tingkat kesantunan pelajar dan mahasiswa dalam memanfaatkan media digital. Suprayitno sebagai Plt Kepala Badan Penelitian dan Pengembangan dan Perbukuan, Kemendikbud menyatakan bahwa, "dua disrupsi digital yang tengah terjadi pada generasi muda di tanah air adalah berupa nilai kesantunan dan penguatan karakter, isu ini menurutnya merupakan bagian dari disrupsi digital yang bisa menjadi sangat permanen dan fundamental sehingga sangat penting menjadi bagian dari program pendidikan saat ini” (Liputan 6, 2021).
Disisi lain, pengguna media sosial dalam menyampaikan informasi seringkali menggunakan bahasa yang tidak baik atau tidak beretika sampai berujung pada persidangan (Diana, 2016:83). Astajaya (2020:82) menambahkan, tren yang berkembang di media sosial saat ini terlihat begitu mudahnya untuk menumpahkan emosi seseorang, hal ini mengartikan bahwa telah terjadi krisis etika dalam berkomunikasi di media sosial.

Persoalan lain adalah sering kali masyarakat percaya begitu saja terhadap berita hoax dan langsung men-share kepada orang lain tanpa memperhitungkan validasi kebenaran dari informasi tersebut. Menurut Laras Sekarasih yang merupakan dosen Psikologi Media dari Universitas Indonesia menyatakan, salah satu sebab dari seseorang mudah menerima informasi tanpa mencari validasi berita tersebut adalah karena kurangnya pengetahuan. Tidak adanya prior knowledge tentang informasi yang diterimanya bisa mempengaruhi seseorang untuk menjadi mudah percaya (Kompas, 2017). Dengan hal ini, tingkat pengetahuan seseorang perlu ditingkatkan supaya tidak mudah percaya dan membagikan berita yang tidak diketahui kebenaran informasinya, sehingga nantinya seseorang dalam berinteraksi dan berkomunikasi dengan orang lain menggunakan konten informasi yang valid bukan hoax maupun kebohongan.

Persoalan serupa juga dialami oleh beberapa lembaga sekolah yang pada saat ini lebih banyak menggunakan media daring, baik dalam pembelajaran maupun dalam berkomunikasi. Salah satu lembaga pendidikan tersebut adalah Madrasah Aliyah Nurul Islam, Ngemplak, Boyolali. Dalam wawancara yang dilakukan, Siti Khairiyah selaku Kepala Madrasah menyatakan bahwa sering terjadi miss-communication antara peserta didik dengan pendidik karena terkadang bahasa yang digunakan dianggap kurang ber-etika. Selain itu, guru sering kali menemukan peserta didik masih mudah termakan berita hoax di media sosial, dan ini perlu menjadi perhatian serius bagi lembaga pendidikan seperti Madrasah. 
Tingkat etika yang rendah dari peserta didik saat berkomunikasi dengan guru harus menjadi perhatian yang serius, sehingga perlu adanya upaya dari lembaga sekolah untuk meningkatkan etika peserta didik dalam berkomunikasi, baik dalam pembelajaran maupun diluar pembelajaran (Khairiyah, 2021). Pemakaian kata yang tidak pantas atau tidak beretika seringkali dianggap oleh peserta didik sebagai bahasa gaul, sehingga mereka tidak sadar bahwa diksi atau pemilihan kata yang mereka pilih merupakan kata-kata yang tidak beretika jika disampaikan, seperti kata bego atau tolol (Junaidi, 2018:70)

Komunikasi sendiri diartikan sebagai proses penyampaian informasi baik berupa pesan, ide, maupun gagasan dari satu pihak kepada pihak yang lain (Adhani, 2014:1). Adanya kemajuan dalam media sosial untuk mempermudah komunikasi antar individu seharusnya dapat disikapi dengan lebih bijak, salah satunya dengan tetap memperhatikan etika dalam menyampaikan informasi tanpa melanggar norma kesopanan. Namun yang terjadi saat ini banyak penyampaian informasi yang dilakukan dengan mengesampikan etika. Salah satu faktor yang menyebabkan kurangnya etika seseorang dalam berkomunikasi adalah tingkat literasi yang rendah (Amalia, 2021). Dengan penjelasan tersebut dapat dipahami bahwa etika komunikasi yang buruk dapat diminimalkan dengan meningkatkan daya baca masyarakat. Ketika masyarakat memiliki pengetahuan yang cukup untuk menyaring dan menimbang apakah perilaku yang akan dilakukannya itu baik atau tidak, maka etika komunikasinya akan menjadi lebih baik.

Dengan berbagai persoalan yang dijelaskan diatas, perlu adanya solusi untuk memperbaiki etika komunikasi khususnya pada diri peserta didik. Salah satu upaya yang dapat dilakukan untuk memperbaiki hal tersebut adalah melalui jalan pendidikan. Pendidikan harus memiliki andil dalam upaya untuk memperbaiki etika komunikasi didalam masyarakat. Dengan jalan pendidikan, etika komunikasi dapat diperbaiki mulai dari peserta didik dilembaga sekolah, kemudian peserta didik dapat menerapkannya didalam keluarga dan juga dalam kehidupan masyarakat. Salah satu tokoh yang memiliki fokus perhatiannya dalam kajian tentang etika adalah KH. Bisri Mustofa. Dalam salah satu karyanya, Bisri Mustofa menjelaskan bahwa, "gunem alus alon lirih ingkang terang, aja kasar aja misuh kaya bujang", berbicaralah dengan halus dan pelanpelan secara jelas, janganlah berbicara dengan cara yang kasar dan berkata kotor seperti yang biasa dilakukan oleh anak muda (Mustofa, 1954:2). Dari kutipan diatas, dapat dipahami bahwa seseorang ketika berkomunikasi dengan orang lain hendaknya menggunakan bahasa yang halus dan dinyatakan dengan pelan-pelan, tidak dengan perkataan yang kasar dan tergesagesa. Hal ini dilakukan agar pesan atau informasi yang akan disampaikan dapat terealisasikan dengan baik kepada komunikan.

Atas dasar itulah maka penelitian dalam kajian ini penting untuk dilakukan. Dalam hal ini, penulis bermaksud menggali bagaimana konsepsi dari Bisri Mustofa kaitannya dengan etika komunikasi didalam masyarakat dan penerapannya di lembaga pendidikan. Sehingga nantinya konsepsi ini dapat digunakan sebagai solusi dalam upaya untuk memperbaiki etika komunikasi peserta didik melalui pendidikan secara lebih luas. Selain itu, konsep ini juga dapat menjadi pertimbangan bahwa pengembangan kurikulum didalam pendidikan seharusnya lebih mengedepankan pada pembentukan dan penanaman etika komunikasi di dalam masyarakat, tidak hanya mengedepankan pada aspek pengetahuan dan aspek keterampilan saja.

KH. Bisri Mustofa merupakan ayah dari KH. Mustofa Bisri atau yang sering dikenal sebagai Gus Mus. Bisri Mustofa lahir pada tahun 1915 M di kampung Sawahan, Kabupaten Rembang, Jawa Tengah. Ia merupakan putra dari pasangan $\mathrm{H}$. Zainal Mustofa dan Chodijah, dengan nama kecil pemberian orang tuanya yakni Mashadi (Huda, 2019:8). Bisri Mustofa memperdalam ilmu agama kepada KH. Bakir, Syaikh Umar Chamdan Al Maghribi, Syekh Maliki, Sayyid Amin, Syaikh Hasan Masysyath, Sayyid Alawi, 
dan KH. Abdul Muhaimin. Hasil karya KH. Bisri Mustofa pada umumnya mengenai masalah keagamaan yang meliputi berbagai bidang, dan secara keseluruhan karya dari Bisri Mustofa berjumlah 176 judul (Huda, 2019:72). Karya yang paling monumental adalah Tafsir Al Ibriz nya yang berjumlah tiga jilid dengan bahasa jawa. Sementara tulisannya yang fokus pada kajian tentang akhlak dan etika adalah Kitab Washoya Al Aba' Lil Abna, Kitab Mitero Sejati, dan Kitab Ngudi Susilo.

Etika adalah ilmu yang menjelaskan dan menilai mengenai apakah perilaku yang dikerjakan itu baik ataupun buruk, salah ataupun benar. Etika merupakan refleksi dari self control seseorang, hal ini dikarenakan segala sesuatunya dilakukan dari dan untuk kepentingan orang atau profesi tertentu (Adhani, 2014:25). Fauzi (2018:10) menambahkan, jika perilaku seseorang dapat diterima dan memberikan dampak positif bagi banyak pihak, maka hal itu akan dinilai kebaikan bagi semua pihak. Sebalinya jika perilaku seseorang merugikan bagi banyak pihak, maka hal itu dapat dinilai sebagai tindakan yang tidak etis untuk dilakukan. Etika berkaitan dengan konsep yang dimiliki individu ataupun kelompok untuk menilai apakah tindakan yang telah dilakukan itu salah atau benar, buruk ataupun baik (Adhani, 2014:25). Sonny (dalam Hidayat \& Rifa'I, 2018:11) kemudian membagi etika kedalam dua macam pembagian, yakni etika deskriptif dan etika normatif. Etika deskriptif membahas mengenai fakta secara apa adanya, yakni mengenai nilai dan perilaku manusia sebagai suatu fakta yang terkait dengan situasi dan realitas yang telah membudaya. Sedangkan etika secara normatif diartikan sebagai norma yang dapat menuntun seseorang untuk memiliki sikap yang ideal, atau sikap yang semestinya dimiliki oleh seseorang dan bernilai dalam hidupnya.

Istilah komunikasi diartikan sebagai sebuah aktivitas perilaku manusia dimana dua individu atau lebih berinteraksi mengenai suau hal, dan dalam hal ini tidak hanya besinggungan dengan persoalan cara berbicara yang efektif namun juga berkaitan dengan bagaimana etika berbicara tersebut dalam menyampaikan informasi (Muslimah, 2016:115). Hoverland (dalam Karyaningsih, 2018:2) menyatakan bahwa komunikasi merupakan sebuah proses dimana seseorang komunikator memberikan rangsangan yang dapat memberikan perubahan perilaku terhadap individu yang lain. adanya perubahan tingkah laku tersebut sesuai dengan apa yang menjadi rangsangan penyampai pesan, sehingga hal ini menandakan bahwa komunikasi yang terjalin tidak ada perbedaan persepsi dan memiliki kesamaan arti antara satu sama lain. Ulya (2016:40), menambahkan bahwa etika seseorang dalam berkomunikasi tidak memiliki hubungan dengan karakteristik individu seperti suku, jenis kelamin, maupun agama. Sehingga semua orang seharusnya dapat menerapkan etika dalam berkomunikasi tanpa adanya alasan dari segi karakteristik individunya.

Ketika dua orang atau lebih melakukan komunikasi, maka keduanya harus memiliki pengertian yang sama terhadap apa yang sedang dibicarakan sehingga tujuan penyampaian pesan dapat terlaksana dengan baik. Hal ini disebut sebagai persepsi, dimana persepsi merupakan inti dari komunikasi, dan penafsiran merupakan inti dari persepsi. Tingkat efektifitas dari sebuah komunikasi yang berjalan antara dua individu bergantung pada keakuratan dalam hal persepsi, sehingga semakin tinggi kesamaan persepsinya maka semakin sering pula mereka berkomunikasi (Karyaningsih, 2018:75). Jika demikian, penerima pesan dapat mengalami salah persepsi manakala penyampai pesan tidak mampu berkomunikasi dengan baik, atau tidak mempedulikan norma dalam berinteraksi dan berkomunikasi. Dengan hal ini, penting untuk diperhatikan mengenai aturan dan norma yang digunakan dalam berinteraksi dan berkomunikasi dengan penerima pesan, sehingga penerima pesan dapat menerimanya dengan baik.

Kemampuan komunikasi dari seseorang bukanlah bakat bawaan atau keturunan, baik dalam bidang tertentu, konteks tertentu, maupun dalam sebuah profesi tertentu. 
Kemampuan komunikasi seseorang dapat dilatih dan diperoleh melalui proses pendidikan dan juga pelatihan baik secara formal maupun non formal (Panuju, 2018:26). Dengan proses pendidikan dan juga latihan inilah, seseorang yang memiliki kemampuan komunikasi rendah baik dalam memahami tata aturan norma dalam berkomunikasi maupun dalam bentuk komunikasinya, dapat ditingkatkan agar kemampuanya menjadi lebih baik. Senada dengan pendapat tersebut, Krisnawati (2020:422) menambahkan bahwa public speaking seseorang dapat dilatih salah satunya dengan mempelajari pada teknik komunikasi, sehingga dengan memperhatikan teknik komunikasi ini akan meningkatkan kemampuan dari public speaking seseorang.

Komunikasi yang paling sering digunakan oleh individu adalah komunikasi secara verbal terutama pembicaraan dengan tatap muka (Karyaningsih, 2018:125). Komunikasi ini seringkali dilakukan dalam lembaga pendidikan untuk menyampaikan materi pembelajaran, yang seringkali dinilai lebih efektif dibandingkan dengan pemberian tugas saja. Hal ini dikarenakan, ketika proses pembelajaran dengan tatap muka dan menggunakan komunikasi verbal, guru akan lebih mudah untuk melihat perkembangan peserta didiknya. Selain komunikasi verbal, seseorang dapat pula menggunakan komunikasi non verbal. Komunikasi non verbal sendiri diartikan sebagai proses komunikasi yang tidak menggunakan kata-kata dalam penyampaiannya namun memiliki makna, baik menggunakan bahasa tubuh, ekspresi muka, maupun melalui nada suara (Karyaningsih, 2018:164).

Komunikasi terbagi menjadi tiga tingkatan, komunikasi intrapersonal, interpersonal, dan kelompok. Komunikasi intrapersonal diartikan sebagai komunikasi yang dilakukan oleh seseorang terhadap dirinya sendiri, hal ini dikarenakan manusia sebagai makhluk rohaniah yang memiliki kemampuan merefleksikan dirinya dan mampu membedakan kapan dirinya sebagai subjek dan kapan diposisikan sebagai objek (Panuju,
2018:55). Sedangkan komunikasi interpersonal diartikan sebagai proses komunikasi yang terjalin antara satu individu dengan individu yang lain secara tatap muka. Satu orang disebut sebagai komunikator atau penyampai pesan, dan yang lain sebagai komunikan atau penerima pesan. Fariastuti (2018:61), menambahkan bahwa bentuk komunikasi ini sering terjadi pada lingkungan sekolah, yang mana sering dilakukan oleh guru sebagai unsur manajemen. Sementara itu, komunikasi kelompok diartikan sebagai proses komunikasi yang terjadi antara tiga orang atau lebih. Hal ini menjadi kodrat dasar manusia, karena manusia terlahir sebagai makhluk sosial yang terus berinteraksi dengan manusia yang lainnya (Panuju, 2018:70).

Sejauh penelusuran peneliti terhadap berbagai sumber pustaka, belum ditemukan hasil penelitian yang fokus pembahasannya mengenai Etika Komunikasi Bisri Mustofa dan penerapannya dalam pendidikan. Dibawah ini akan diuraikan mengenai beberapa kajian pustaka yang relevan dengan penelitian yang akan dilakukan oleh penulis.

Penelitian yang dilakukan oleh Astajaya, (2020) dengan fokus penelitian pada etika komunikasi di media sosial. Penelitian ini memiliki kajian pada bagaimana supaya masyarakat dapat lebih bijaksana dalam menggunakan media sosial, terlebih dengan diterbitkannya UU ITE yang mengatur tentang media sosial. Kesimpulan dari penelitian tersebut menganjurkan pada masyarakat untuk dapat menyaring informasi secara lebih baik, dan setiap lembaga dapat memberikan pengajaran bagaimana berkomunikasi dalam media sosial secara baik dan benar.

Penelitian yang dilakukan oleh Pratopo, (2018) fokus kajian yang diteliti adalah bagaimana pandangan tokoh pers Indonesia mengenai etika pada media baru. Dengan menggunakan metode deskriptif kualitatif, penelitian ini menghasilkan kesimpulan bahwa para tokoh pers Indonesia memiliki kesamaan idealisme mengenai jurnalisme dan etika jurnalistik, meskipun tentunya ada beberapa perbedaan yang mendasar seperti satu tokoh lebih condong pada pandangan secara normatif 
formal, dan tokoh yang lain memiliki pandangan utilitarian liberal.

Penelitian yang dilakukan oleh Mannan, (2019) dengan fokus penelitian pada etika komunikasi interpersonal mahasiswa kepada dosen. Tujuan penelitian adalah untuk mengetahui etika komunikasi interpersonal mahasiswa terhadap dosen melalui smartphone, dan mengetahui faktor-faktor penyebab kurangnya etika komunikasi dari mahasiswa saat berkomunikasi dengan dosen. Dengan menggunakan metode deskriptif kualitatif, penelitian ini dapat menyimpulkan bahwa etika komunikasi interpersonal mahasiswa terhadap dosen dianggap tidak beretika dan tidak sopan disebabkan karena tidak mengikuti aturan yang berlaku. Selain tidak mencantumkan identitas, seringkali mahasiswa cenderung to the point dalam berkomunikasi kepada dosen dengan menggunakan smartphone.

Penelitian yang dilakukan oleh Muiz dan Suprianto, (2018) dengan fokus kajian pada etika komunikasi Islam dalam mensikapi hoax di media sosial dengan tempat penelitian di masjid Al Ukhuwah perum permata sukodono raya. Tujuan penelitian adalah untuk menjelaskan apakah berita hoax mampengaruhi sikap dari para jama'ah yang menjadi objek penelitian. Dengan menggunakan metode deskriptif kuantitatif, kajian ini dapat menyimpulkan bahwa jama'ah masjid yang menjadi objek penelitian memiliki tingkat kedewasaan yang baik, dengan mengedepankan sikap kehati-hatian untuk mencegah diri agar tidak melakukan sesuatu yang membahayakan dirinya maupun orang lain. Hal ini sesuai dengan prinsip yang diajarkan dalam Islam dan telah difatwakan oleh MUI tentang hukum dan pedoman bermuamalah di media sosial.

Penelusuran yang peneliti temukan memang banyak membahas mengenai etika komunikasi, namun perbedaan dengan penelitian yang akan dilakukan adalah pada fokus kajian, dimana penulis memiliki fokus pada bagaimanakah konsepsi etika komunikasi dari Bisri Mustofa dan bagaimana penerapan konsepsi ini dapat diajarkan didalam pendidikan khususnya di MA Nurul Islam
Boyolali, sehingga dunia pendidikan memiliki andil dalam memperbaiki etika komunikasi masyarakat. Hal inilah yang membedakan penelitian yang penulis buat dengan penelitian yang telah ada sebelumnya.

Penelitian ini dilakukan dengan tujuan pada pengungkapan konsep etika komunikasi dari Bisri Mustofa yang kemudian dilihat bagaimana penerapan konsep tersebut didalam proses pembelajaran di lembaga pendidikan. Penelitian ini didasarkan pada pendapat Panuju (2018:26), bahwa kemampuan komunikasi seseorang dapat dilatih dan diperoleh melalui proses pendidikan dan juga pelatihan baik secara formal maupun non formal, baik dalam bidang tertentu, konteks tertentu, maupun dalam sebuah profesi tertentu. Penelitian ini akan melihat secara komprehensif baik dari ranah tujuan pembelajaran yang dilaksanakan, kemudian metode pembelajaran yang digunakan, maupun proses evaluasi yang dilakukan pada proses pembelajaran yang berlangsung, sehingga diharapkan nantinya dapat diperoleh kesimpulan berkaitan dengan bagaimana penanaman etika komunikasi Bisri Mustofa dalam proses pembelajaran di MA Nurul Islam Boyolali.

\section{METODOLOGI PENELITIAN}

Setiap penelitian pastinya menggunakan suatu paradigma tertentu yang digunakan sebagai kacamata kajian. Paradigma yang digunakan dalam penelitian ini adalah paradigma konstruktivism-interpretatif, paradigma ini memiliki pandangan bahwa kenyataan merupakan hasil dari sebuah konstruksi atau bentukan dari manusia. Kenyataan ada sebagai hasil dari kemampuan berpikir seseorang. Selain itu, paradigma ini juga berpendapat bahwa pengetahuan bukan hanya merupakan hasil dari pengalaman terhadap fakta, namun juga merupakan hasil dari sebuah konstruksi pemikiran subjek yang diteliti (Batubara, 2017:104). Sehubungan dengan hal tersebut, kemampuan komunikasi seseorang dapat dikonstruksi menjadi lebih baik dengan melalui latihan-latihan dan pendidikan. Kemampuan yang dimaksud dapat 
berupa public speaking, etika, penampilan, dan juga kepribadian. Semua kemampuan tersebut dapat ditingkatkan melalui sebuah proses pendidikan, baik pendidikan formal maupun non formal (Panuju, 2018:26-27).

Penelitian ini merupakan penelitian lapangan (field research) yang bersifat kualitatif dengan pendekatan studi kasus. Pendekatan studi kasus digunakan untuk mengeksplorasi atas suatu kasus tertentu dengan penggalian data secara mendalam (Creswell, 2015). Subyek penelitiannya adalah Guru Pendidikan Agama Islam dan Kepala Madrasah di MA Nurul Islam Boyolali. Ditentukan menggunakan sampel purposive dengan mengambil beberapa narasumber yang dianggap mengetahui secara mendalam terkait persoalan dan permasalahan yang ada diwilayah penelitian, yakni MA Nurul Islam Boyolali. Pengumpulan data dilakukan melalui teknik wawancara, observasi, dan dokumentasi. Data yang diperoleh kemudian dilakukan analisis secara mendalam dengan cara telaah seluruh data yang terkumpul dari berbagai sumber tersebut. Data yang terkumpul kemudian dilakukan analisis melalui tiga tahapan, yakni reduksi data, penyajian data, dan penarikan kesimpulan (Matthew \& Huberman, 2009:20).

\section{HASIL DAN PEMBAHASAN}

\section{Konsep Etika Komunikasi Bisri Mustofa}

Sesuai dengan tujuan penelitian yang dilakukan, analisis yang telah dilakukan terhadap karya-karya dari Bisri Mustofa dapat dikontruksikan mengenai konsep etika komunikasi dan konsep tersebut dapat diajarkan dalam proses pembelajaran. Karyaningsih (2018:125) menyebutkan bahwa komunikasi dapat terjalin dalam dua bentuk, yakni komunikasai verbal dan non verbal. Menurut Bisri Mustofa, dalam melakukan komunikasi dalam bentuk verbal, sebaiknya menggunakan cara yang lembut, pelan-pelan, namun isinya jelas. Tidak menggunakan bahasa yang kasar, apalagi sampai menggunakan kata makian, hal ini ditujukan supaya komunikan dapat menerima informasi dari komunikator dengan perasaan yang baik sehingga mampu menangkap pesan informasi dengan utuh. Dalam kitabnya, Bisri Mustofa (Ngudi Susilo:2) menjelaskan, "gunem alus alon lirih ingkang terang, aja kasar aja misuh kaya bujang", berbicaralah dengan halus dan pelanpelan secara jelas, janganlah berbicara dengan cara yang kasar dan berkata kotor seperti yang biasa dilakukan oleh anak muda.

Komunikasi lain dapat berupa komunikasi non-verbal, komunikasi ini biasanya menggunakan bahasa tubuh, ekspresi muka, maupun nada suara (Karyaningsih, 2018:164). Dalam melakukan komunikasi non-verbal, etika yang perlu diperhatikan adalah dengan menghadapkan pandangan padanya dan mendengarkan secara seksama. Bahasa tubuh ini menandakan keseriusan seseorang dalam mendengarkan informasi yang disampaikan. Hal ini sesuai dengan apa yang dijelaskan Bisri Mustofa dalam kitabnya (Mitero Sejati:4), "lamon siro diomongi dening liyan, kudu madep mirengaken kang temenan", ketika kita diajak berbicara oleh orang lain, sikap kita haruslah menghadapkan pandangan kepadanya dengan mendengarkan apa yang dibicarakan secara serius.

Panuju (2018:55) membagi tingkatan komunikasi menjadi tiga, yakni intrapersonal, interpersonal, dan kelompok. Komunikasi dapat terjadi pada diri sendiri, pada dua orang tertentu, dan juga pada kelompok orang tertentu. Bisri Mustofa dalam kitabnya (Mitero Sejati:4) menjelaskan, "lamon siro omong iku kudu manis, aja kasar aja rewel lan ceriwis. Tembung iro aja ana kang natoni, ring atine liyan mundak diwaneni". Dari kutipan tersebut, etika komunikasi interpersonal yang dapat dilaksanakan adalah ketika kita ingin berbicara, harus menggunakan bahasa yang baik, tidak dengan bahasa yang kasar dan bertele-tele. Selain itu, pemilihan kata yang digunakan jangan sampai menyakiti hati orang lain, hal ini dikhawatirkan akan dibalas dikemudian hari. Jika hal ini disadari dan dilaksanakan oleh setiap orang, maka ujaran kebencian dan hoax akan mudah untuk diminimalisir. 
Selain komunikasi interpersonal, komunikasi juga dapat dilaksanakan dalam lingkup kelompok tertentu. Sama seperti komunikasi interpersonal, komunikasi dalam kelompok juga harus memperhatikan etika dengan menggunakan bahasa yang baik dan kata-kata yang halus. Namun menurut Bisri Mustofa, ada beberapa hal yang perlu diperhatikan dalam etika komunikasi kelompok. Dalam kitabnya (Mitero Sejati:4), ia menjelaskan bahwa, "lamon siro hajat takon kudu kanti, yen wis rampung ngendikane kanti titi. Lamon liyan ditakoni aja pisan, siro lancang jawab kaya wong brangasan". Ketika berbicara dalam suatu forum dan memiliki keinginan untuk bertanya, kita harus menunggu orang lain menyelesaikan dulu pembicaraannya. Dan ketika orang lain mendapatkan pertanyaan sedangkan kita mengetahui jawabannya, jangan sampai kita mendahului untuk menjawabnya tanpa dipersilahkan terlebih dahulu. Etika ini penting untuk diperhatikan dalam berkomunikasi pada suatu forum supaya forum tersebut dapat berjalan dengan lancar, seperti halnya dalam diskusi kelompok.

Kesimpulan yang dapat diambil dari pemikiran Bisri Mustofa mengenai etika adalah bahwa dalam berkomunikasi harus memperhatikan pemilihan kata yang tepat, tidak menggunakan kata makian, dengan intonasi yang pas tidak terlalu cepat. Selain itu dalam komunikasi interpersonal maupun kelompok, tetap memperhatika etika baik secara verbal maupun non verbal. Konsepsi etika komunikasi yang telah dijelaskan diatas akan memiliki dampak yang signifikan apabila ditanamkan pada masyarakat. Upaya yang dapat dilakukan adalah dengan menanamkan konsepsi etika komunikasi tersebut melalui pendidikan. Seperti yang dijelaskan oleh Panuju (2018: 26), bahwa kemampuan komunikasi dari seseorang dapat dilatih dan ditingkatkan melalui proses pendidikan, baik dari kemampuan pengucapan maupun etika dalam melakukan komunikasi. Jika diselaraskan dengan konsepsi Bisri Mustofa, maka hal tersebut dapat dilakukan dengan memperhatikan pada tujuan pendidikan, metode pembelajaran yang digunakan, dan juga evaluasi pembelajaran yang dilaksanakan.

\section{Tujuan Pendidikan}

Tujuan pendidikan didalam undangundang Sisdiknas adalah untuk berkembangnya potensi peserta didik agar menjadi manusia yang beriman dan bertakwa kepada Tuhan Yang Maha Esa, berakhlak mulia, sehat, berilmu, cakap, kreatif, mandiri, dan menjadi warga negara yang demokratis serta bertanggung jawab (UU Sisdiknas, 2003). Tujuan pendidikan menurut Bisri Mustofa dapat dilihat dalam kitabnya (Ngudi Susilo:910), didalamnya dijelaskan "Luru ngilmu iku perlu nanging, budi adab islam kudu tansah dipersudi, Akeh bocah pinter nanging ora bagus, budi pekertine sebab do gemagus". Dari kutipan tersebut, tujuan pendidikan seharusnya tidak hanya pada peningkatan pengetahuan tetapi juga harus memperhatikan adab kesopanan dan budi pekerti. Hal ini didasarkan pada fenomena banyaknya orang pintar dalam pengetahuan, namun budi pekerti dan adab kesopanannya rendah. Banyak pelaku koruptor merupakan orang-orang yang pandai dengan pendidikan yang tinggi. Hal ini menjadi catatan bahwa tingginya pendidikan seseorang saat ini, tidak menjamin perilaku dan akhlak seseorang tersebut baik, sehingga tujuan pendidikan saat ini perlu memperhatikan pada perbaikan etika, tata krama, akhlak, dan budi pekerti. Dengan memperhatikan pada perbaikan tersebut, perilaku-perilaku masyarakat yang menyimpang dari norma dan etika dapat diperbaiki.

\section{Metode Pembelajaran}

Sejalan dengan tujuan pendidikan diatas, tujuan pendidikan yang diinginkan dapat terealisasikan dengan baik melalui bantuan metode pembelajaran. Metode pembelajaran diperlukan sebagai cara ataupun tahapan yang dilakukan dalam proses pembelajaran antara peserta didik dan pendidik guna mencapai pada tujuan pembelajaran (Afandi, 2013:16). metode yang dapat digunakan untuk menanamkan etika 
yang baik menurut Bisri Mustofa adalah dengan metode pembiasaan dan reward \& punishment. Budal ngaji awan bengi sekabehe, toto kromo lan adabe podo bae (Mustofa, Ngudi Susilo:4). Terkandung penjelasan bahwa dalam upaya penanaman etika terhadap diri seseorang salah satunya dapat dilakukan dengan jalan pembiasaan diri, dengan membiasakan diri baik siang maupun malam untuk berperilaku dengan tata krama dan juga etika yang baik. Metode pembiasaan ini dikenal sebagai salah satu metode pembelajaran yang efektif untuk menanamkan karakter peserta didik, hal ini disebabkan oleh perilaku yang dilakukan secara berulang-ulang sehingga akan menjadi kebiasaan dalam kehidupan sehari-hari (Ahsanulkhaq, 2019:23).

Selain metode pembiasaan diri, penanaman etika yang baik pada diri seseorang dapat juga dilakukan dengan menggunakan metode reward \& punishment. Hal ini dapat dilihat dalam kutipan sebagai berikut : "Aku wis diwulang ngilmu tajwid, ngilmu tauhid lan liyan-liyane. Lan aku yowis di wulang toto kromo. Bapak lan ibu ketoro seneng banget bareng pirso yen aku mundak pinter lan mundak bagus toto kromone. Tandane aku di tukoake klambi bagus banget. (Mustofa, Washoya:18)". Metode ini merupakan metode pembelajaran interaktif antara guru dan peserta didik yang menerapkan sistem pemberian hadiah bagi peserta didik yang aktif dan benar dalam menjawab soal latihan (Muliawan dalam Kusyairy, 2018:81). Sehingga dengan metode ini, peserta didik akan termotivasi untuk melakukan perilaku yang dapat mendatangkan reward dan menjauhi perilaku maupun sikap yang menyebabkan dirinya mendapatkan punishment.

\section{Evaluasi Pembelajaran}

Selain tujuan dan metode pembelajaran, komponen terpenting dalam pembelajaran yang difokuskan pada penanaman etika yang baik pada seseorang adalah pada evaluasi pembelajarannya. Evaluasi sendiri digunakan untuk menentukan nilai dari suatu objek penilaian berdasarkan pada ukuran tertentu, dimana sebagai objek penilaianya adalah hasil belajar dari peserta didik (Suarga, 2019:329). Dengan adanya evaluasi dalam pembelajaran, maka dapat dilihat materi apa saja yang belum dipahami oleh peserta didik dan materi yang telah dikuasai oleh mereka. Dari hal ini, guru dapat memberikan tanggpan atas evaluasi pembelajaran, sehingga materi secara keseluruhan dapat dipahami oleh peserta didik. Berkaitan dengan evaluasi pembelajaran, Bisri Mustofa menjelaskan dalam kitabnya (Washoya: 21-22) berikut ini : "Pak guru sabar banget, nanging yen ono bocah guyon ono ing pamulangan yo banjur duko. Aku ora wani guyon ing pamulangan, mundak di dukani." Dari kutipan diatas, terkandung penjelasan bahwa evaluasi pembelajaran dapat dilakukan dengan melakukan pengamatan terhadap perilaku seseorang ataupun peserta didik secara langsung. Pengamatan secara langsung ini dapat dikatakan sebagai penilaian dengan instrumen yang berupa observasi. Didalam lampiran Permendikbud No 104 tahun 2014 dijelaskan bahwa, observasi merupakan intrumen yang dapat dilakukan untuk mengamati sikap dan perilaku keseharian peserta didik yang direkam melalui sebuah pengamatan (Permendikbud 104:13).

Dari penjelasan diatas, konsepsi etika komunikasi dari Bisri Mustofa akan memiliki dampak yang signifikan apabila ditanamkan pada masyarakat melalui pendidikan. Caranya adalah dengan memperhatikan pada tujuan pembelajaran, metode pembelajaran, dan evaluasi pembelajaran. Dimana tujuan pembelajaran yang diinginkan difokuskan pada pembentukan etika yang baik pada peserta didik, kemudian metode pembelajaran yang digunakan adalah menggunakan metode pembiasaan atau reward \& punishment, dan evaluasi pembelajaran yang digunakan adalah menggunakan pengamatan atau observasi secara langsung, agar diketahui sampai sejauh mana efektifitas penanaman etika tersebut telah dilaksanakan.

Beberapa hal yang dapat menjadi penyebab dalam rendahnya etika komunikasi peserta didik adalah pengaruh konten negatif 
dari media sosial, televisi, majalah dan sumber lainnya yang dapat memberikan pengaruh terhadap perilaku seseorang. Selain itu, pengendalian emosi dari diri peserta didik sendiri menjadi pengaruh yang signifikan dalam peningkatan etika dalam melakukan komunikasi. Pengendalin emosi ini dapat dipengaruhi dari faktor bawaan maupun faktor lingkungan. Faktor bawaan dimaksudkan pada adanya faktor keturunan yang menyebabkan beberapa perilaku peserta didik melanggar etika. Dan faktor lingkungan merupakan faktor luar dari diri peserta didik yang dapat mempengaruhi tinggi rendahnya etika dalam diri peserta didik (Fitriani, 2019:94). Sehingga, etika komunikasi dari seseorang tidak hanya didasarkan pada kemampuan intelektualnya saja, namun juga perlu diperhatikan pada kecerdasan emosionalnya (Novrianto, 2019:3).

Madrasah Aliyah Nurul Islam Boyolali sebagai lembaga pendidikan yang memiliki persoalan pada etika komunikasi, melakukan upaya untuk memperbaiki tingkat etika kesopanan peserta didik. Salah satunya dilaksanakan oleh Ibu Siti Musfirotun, yang merupakan guru pendidikan agama Islam di MA Nurul Islam Boyolali khususnya dalam mata pelajaran Qur'an Hadis. Ia pernah mengenyam pendidikan di pesantren dan mengkaji beberapa bidang kajian seperti akhlak dan etika. Diantara kitab yang dikaji adalah Ta'limul Muta'alim, Adabul Muta'alim, Ngudi Susilo, dan Washoya (Musfirotun, 2021). Menurutnya, salah satu upaya yang dilakukan dalam memperbaiki etika komunikasi peserta didik adalah dengan memperhatikan tujuan pembelajaran pada rencana pelaksanaan pembelajaran (RPP) yang dibuat. Seperti contoh dalam materi "membangun budaya kritis melalui dakwah", salah satu tujuan pembelajarannya adalah peserta didik mampu untuk melakukan perdebatan atau diskusi dengan cara yang baik, dengan menggunakan bahasa yang baik dan etika yang baik. memberikan informasi yang sangat efektif kepada mahasiswa dengan menentukan tema dan materi dengan orientasi agar mampu memberikan informasi kepada siswa. (Listianingrum et al., 2021)

Dengan ini, peserta didik diharapkan dapat menerapkannya pada semua tempat tidak hanya ketika berdiskusi didalam kelas, namun ketika berkomunikasi dengan semua warga sekolah, baik dengan guru dan teman sebayanya. Hal ini sesuai dengan konsep etika komunikasi Bisri Mustofa, dimana tujuan pendidikan seharusnya tidak hanya mengutamakan pada penguasaan ranah kognitif saja, namun juga mengedepankan ranah afektif dengan penekanan pada peningkatan etika dalam berkomunikasi dengan orang lain.

Upaya lain yang dilakukan adalah dengan memfokuskan pada satu materi tertentu untuk meningkatkan etika dalam berkomunikasi bagi para peserta didik. Ketika berdiskusi dikelas misalnya, peserta didik dilatih untuk bisa menggunakan bahasa dan etika yang baik. Seperti contohnya mengawali perkataan dengan salam, kemudian jika ingin memberikan tanggapan pada diskusi terlebih dahulu meminta ijin kepada moderator, ataupun pemilihan diksi kata yang digunakan saat berdiskusi tidak menggunakan kata yang kasar dan tidak pantas. Selain itu, adanya teguran dan sanksi untuk peserta didik yang memiliki etika kurang baik saat pembelajaran diharapkan dapat menjadi pelajaran, agar mereka lebih memperhatikan etika saat berkomunikasi. Wujud dari reward yang seringkali dilakukan adalah dengan memberikan apresiasi berupa nilai yang baik dalam ranah afektif jika peserta didik dapat menyampaikan pendapat dengan memperhatikan etika, norma dan diksi yang baik. Selain itu juga memberikan teguran secara langsung sebagai wujud dari punishment jika peserta didik melakukan diskusi dengan katakata yang tidak pantas. Hal ini dilakukan agar apa yang menjadi kelebihan dapat dipertahankan dan apa yang menjadi kekurangan dapat diperbaiki dikemudian hari (Musfirotun, 2021).

Selain penggunaan metode reward \& punishment untuk meningkatkan etika peserta didik, dalam rencana pelaksanaan pembelajaran yang disusun juga menjelaskan mengenai 
evaluasi pembelajaran yang menggunakan lembar pengamatan untuk menilai pada sisi aspek sikapnya. Berkaitan dengan hal tersebut, guru sebagai fasilitator dalam sebuah pembelajaran harus melakukan monitor secara langsung untuk perilaku mereka, baik secara lisan maupun pada gerakan tubuh saat pembelajaran berlangsung. Mengamati secara langsung dapat memberikan tingkat efektifitas yang lebih baik karena guru dapat langsung memberikan feedback kepada siswa agar mereka langsung memperbaiki apa yang menjadi kesalahannya. Hal ini telah dilakukan dan memiliki tingkat efektifitas yang bagus. Terbukti dengan beberapa kali guru melakukan teguran dan nasihat kepada peserta didik yang terkadang mengggunakan kata atau diksi yang kurang sopan saat berdiskusi, dan hal ini telah menjadi perhatian peserta didik sehingga mereka dapat memperbaikinya dikemudian hari (Musfirotun, 2021). Disisi lain, dalam rangka penanaman perilaku akhlak mulia dan etika yang baik terhadap peserta didik, tidak dilakukan hanya saat pembelajaran saja, namun disore hari Madrasah Aliyah Nurul Islam Boyolali juga memberikan materi tambahan berupa kajian kitab kuning seperti Aqidatul Awam, Ngudi Susilo, dan Akhlakul Banin. Semua dilakukan dalam upaya untuk meningkatkan keimanan, ketaqwaan, dan akhlak mulia peserta didik khususnya etika dalam berkomunikasi didalam lingkungan sekolah (Khairiyah, 2021).

\section{SIMPULAN}

Konsepsi Bisri Mustofa dalam pendidikan etika ialah memberikan perhatian khusus pada bagaimana menyampaikan informasi kepada orang lain dengan bahasa yang baik, bahasa yang halus, dan tidak menyakiti perasaan seseorang yang diajak berkomunikasi. Etika ini dilakukan baik ketika berkomunikasi menggunakan komunikasi verbal maupun non-verbal dan pada komunikasi yang terjalin antara dua orang ataupun lebih. Konsep etika komunikasi ini dapat ditanamkan pada masyarakat melalui jalan pendidikan, yakni dengan memperhatikan pada tujuan pembelajaran yang akan dilaksanakan, metode pembelajaran yang akan digunakan, dan evaluasi atau penilaian pembelajaran yang akan dilaksanakan. Dalam penerapannya, Madrasah Aliyah Nurul Islam Boyolali mengupayakan penerapan konsepsi tersebut dengan memperhatikan pada rencana pelaksanaan pembelajaran (RPP) dan proses pembelajarannya, yakni dengan cara mefokuskan pada salah satu materi pokok yang diajarkan dimana tujuan pembelajarannya adalah untuk melatih siswa agar dapat menggunakan etika yang baik saat berdiskusi dalam pembelajaran, selain itu pendidik juga menggunakan metode berupa metode reward \& punishment sebagai metode pembelajaran, dan juga lembar pengataman (observasi) sebagai intrumen dalam evaluasi pembelajarannya.

\section{DAFTAR PUSTAKA}

Adhani, R. (2014). Etika dan Komunikasi. Grafika Wangi Kalimantan.

Afandi, M., Evi Chamalah \& Oktarina PW. (2013). Model Dan Metode Pembelajaran Di Sekolah. Unissula Press.

Ahsanulkhaq, M. (2019). Membentuk Karakter Religius Peserta Didik Melalui Metode Pembiasaan. Jurnal Prakarsa Paedagogia. 2 (1). https://doi.org/10.24176/jpp.v2i1.4312

Amalia, Y. (2021, Maret 4). Tingkat Literasi Pengaruhi Etika Bermedia Sosial. Diakses dari https://www.merdeka.com/peristiwa/tin gkat-literasi-pengaruhi-etika-bermediasosial.html

Astajaya, I K. M. (2020). Etika Komunikasi Di Media Sosial. Jurnal Ilmiah Ilmu Agama dan Ilmu Sosial Budaya, 15 (1). http://dx.doi.org/10.25078/wd.v15i1.16 78

Batubara, J. (2017). Paradigma Penelitian Kualitatif dan Filsafat Ilmu Pengetahuan dalam Konseling. Jurnal Fokus Konseling. $3 \quad$ (2). https://doi.org/10.26638/jfk.387.2099 
Creswell, J. W. (2015). Penelitian Kualitatif \& Desain Riset. Yogyakarta: Pustaka Pelajar.

Dewi, B. K. (2021, Februari 26). Netizen Indonesia Paling Tidak Sopan Se-Asia Tenggara, Pengamat Sebut Ada 3 Faktor Penyebab. Diakses dari https://www.kompas.com/sains/read/20 21/02/26/194500523/netizenindonesia-paling-tidak-sopan-se-asiatenggara-pengamat-sebut-ada3? page $=$ all

Diana, N. (2016). Pengaruh Teknologi Informasi dan Komunikasi Terhadap Etika Berbahasa Mahasiswa. Jurnal Itqan. 7 (1).

Fariastuti, I. (2018). Pengaruh Komunikasi Interpersonal dan Budaya Sekolah Terhadap Motivasi Belajar SMK Al Ikhwaniyah Tangerang Selatan. Jurnal Pustaka Komunikasi. 1 (1). https://doi.org/10.32509/pustakom.v1i1 .543

Fauzi, I. (2018). Etika Profesi Keguruan. IAIN Jember Press.

Fitriani, E. (2019). Peranan Layanan Bimbingan Kelompok dalam Mengendalikan Emosi dan Etika Komunikasi Siswa SMP Swasta Silinda. Jurnal Pendidikan dan Pembelajaran $\begin{array}{llll}\text { Terpadu } & \text { (JPPT). } & 1 & \text { (2). }\end{array}$ https://doi.org/10.32696/pgsd.v1i2.361

Hidayat, R. dan Rifa'I, M. (2018). Etika Manajemen Perspektif Islam. Lembaga Peduli Pengembangan Pendidikan Indonesia (LPPPI).

Huda, A. Z (2019). Mutiara Pesantren: Perjalanan Khidmah KH. Bisri Mustofa. LKIS.

Junaidi. (2018). Analisis Etika Komunikasi Siswa Melalui Pendidikan Karakter Islami Di SMA Kota Tangerang Selatan. Jurnal Elsa: Edukasi Lingua Sastra. 16 https://doi.org/10.47637/elsa.v16i2.95

Karyaningsih, P. D. (2018). Ilmu Komunikasi. Samudra Biru.
Khairiyah, S. (13 Juli 2021). Wawancara Pribadi

Kompas. Mengapa Banyak Orang Mudah Percaya Berita Hoax ?. (2017, Januari 23). Diakses dari https://nasional.kompas.com/read/2017 /01/23/18181951/mengapa.banyak.oran g.mudah.percaya.berita.hoax.?page $=$ all

Krisnawati, W. (2020). Pelatihan etika Komunikasi Public Speaking untuk Para Perangkat Desa Pucung Balongpanggang Gresik. Jurnal of Community Service. 2 (3). http://dx.doi.org/10.30587/dedikasimu. $\mathrm{v} 2 \mathrm{i} 3.1643$

Kusyairy, U. (2018). Meningkatkan Hasil Belajar Peserta Didik dengan Memberikan Reward \& Punishment. Jurnal Pendidikan Fisika. 6 (2). https://doi.org/10.24252/jpf.v6i2.5595

Lampiran Permendikbud No. 104 th 2014, tentang Penilaian Hasil Belajar Oleh Pendidik pada Pendidikan Dasar dan Pendidikan Menengah.

Liputan 6. Kemendikbud Soroti Kesantunan Pelajar dan Mahasiswa dalam Manfaatkan Media Digital. (2021, April 03). Diakses dari https://www.liputan6.com/news/read/4 522176/kemendikbud-sorotikesantunan-pelajar-dan-mahasiswadalam-manfaatkan-media-digital

Listianingrum, R., Fitriana Poerana, A., \& A. Arindawati, W. (2021). Strategi Komunikasi Melalui Media Instagram Dalam Memberikan Informasi Kepada Mahasiswa. Jurnal Pustaka Komunikasi, 4(1), 11-23. https://doi.org/10.32509/pustakom.v4i1 .1309

Matthew, B. Miles. \& A. M. Huberman. (2009). Analisis Data Kualitatif: buku sumber tentang metode-metode baru. Jakarta: UI Press.

Mannan, A. (2019). Etika Komunikasi Interpersonal Mahasiswa Ilmu Komunikasi Fakultas Dakwah dan Komunikasi Kepada Dosen Melalui 
Smartphone. Jurnal Aqidah, 5 (1). https://doi.org/10.24252/aqidahta.v5i1. 10062

Muiz, A. H. dan Suprianto. (2018). Etika Komunikasi Islam dalam Mensikapi Berita Hoax di Media Sosial. Jurnal Masjiduna, 1 http://dx.doi.org/10.52833/masjiduna.v $1 \mathrm{ii1.24}$

Musfirotun, S. (13 Juli 2021). Wawancara Pribadi

Muslimah. (2016). Etika Komunikasi Dalam Perspektif Islam. Jurnal Sosial Budaya. $13(2)$.

http://dx.doi.org/10.24014/sb.v13i2.35 $\underline{34}$

Mustofa, B. (1954). Ngudi Susilo. Menara Kudus.

Mustofa, B. Mitero Sejati. Maktabah Muhammad bin Ahmad Nabhan.

Mustofa, B. Washoya Al abaa Lil Abnaa. Menara Kudus.

Novrianto, LM. (2019). Analisis Hubungan Kecerdasan Emosional Dengan Etika Komunikasi Mahasiswa Dalam Menciptakan Atmosfir Akademik Di Universitas Islam Makassar. Medialog: Jurnal Ilmu Komunikasi. 2 (2). https://doi.org/10.35326/medialog.v2i2. 323

Nurrachmi, S dan Puspita, R. (2018). Etika Komunikasi Netizen Di Media Sosial. Jurnal Ilmu Komunikasi UPN Veteran Jatim. 1 https://doi.org/10.33005/jkom.v1i1.5

Panuju, R. (2018). Pengantar Studi Ilmu Komunikasi. Prenadamedia.

Pratopo, W. M. (2018). Pandangan Tokoh Pers terhadap Etika Media Baru. Jurnal Pustaka Komunikasi. 1 (1). https://doi.org/10.32509/pustakom.v1i1 .554

Suarga. (2019). Hakikat, Tujuan, Dan Fungsi Evaluasi Dalam Pengembangan Pembelajaran. Jurnal Inspiratif Pendidikan. 8 (2). https://doi.org/10.24252/ip.v8i2.12344
Ulya, E. D., Saleh, A. dan Priatna, W. B. (2016). Penerapan Etika Komunikasi Interpersonal Pada Mahasiswa Program Diploma IPB. Jurnal Komunikasi Pembangunan. $14 \quad$ (1). https://doi.org/10.46937/14201613550

Undang-Undang Dasar Negara Republik Indonesia Tahun 1945.

Undang-Undang Republik Indonesia No 12 Tahun 2012 tentang Pendidikan Tinggi.

Undang-undang Sisdiknas No 20 Tahun 2003 tentang Sistem Pendidikan Nasional. 